\title{
Identity and Idiolect: Code-switching as Identity Marker in Chris Claremont's Uncanny X-Men and New Mutants
}

\author{
Annie Burman
}

\begin{abstract}
During Chris Claremont's run as author of Uncanny X-Men after the relaunch of the comic in 1975, several new characters were introduced, leading to the diversification of the title team. The previously all-American, Christian, white male-dominated team became more heterogenous in terms of ethnicity, nationality, religion and gender. Claremont's X-Men 1983 spin-off, New Mutants also featured several minority characters. A part of this new diversity was the occurence of codeswitching, the act of switching between two languages within one conversation. Many of the characters who are not native speakers of English, for example Nightcrawler, Colossus, Karma and Sunspot, regularly code-switch into their native language. The characters develop their own idiolect, which makes their speech instantly recognisable to the reader, while at the same time serving as a reminder of their origins and their back-story.

However, not all non-native speakers of English code-switch in the comics. Languages that readers would be less likely to recognise do not feature, and characters whose linguistic identity is complex, due to, for example, multilingualism or displacement from the country to which their native language is generally associated, do not code-switch. The fact that the code-switching in the comics bears little resemblance to real-life code-switching by non-native speakers, since it consists mostly of reoccurring phrases such as exclamations and appellatives, implies that the code-switching is not an attempt at realism.
\end{abstract}

This chapter explores the use of code-switching in Chris Claremont's Uncanny XMen and New Mutants to convey linguistic and national identity. I will consider not only when code-switching occurs, but also when it does not, and suggest reasons for this, ranging from implications about the character's identity to the practical problems of bringing possibly unfamiliar phrases into the dialogue.

Key Words: Bilingualism, code-switching, identity, language usage, diversity, Marvel Comics.

$* * * * *$

In recent years, there has been a rising interest in the language of comics. An anthology on the topic, edited by Frank Bramlett, appeared in 2012, and includes articles exploring everything from linguistic codes to plurilingualism. In the case of Marvel, the scholarship has mostly discussed the use of dialects, which plays an important role in the portrayal of many characters. ${ }^{1}$ In this chapter, I will explore 
another linguistic phenomenon, code-switching, and how this is used in Chris Claremont's Uncanny X-Men and New Mutants to indicate identity. ${ }^{2}$

The terminology of code-switching is often disputed and the same term may be used in different ways by different scholars. For the purpose of this paper, I will use a version of Shana Poplack's definition, where code-switching is any instance of two languages occurring within one speech act. ${ }^{3}$ The three main types of codeswitching outlined by Poplack are intrasentential (when the switch occurs within a clause or sentence), intersentential (when the switch occurs at a clause or sentence boundary), and tagswitching (the insertion of a tag in a different language). ${ }^{4}$ As tags are not subject to the clause's syntax, tagswitching is the simplest kind of code-switch. Intrasentential switches carry with them 'the greatest syntactic risk', as the languages come in such close proximity to one another, with no boundaries to keep them apart. ${ }^{5}$ In early studies of bilingualism and code-switching around the 1960 s, it was assumed that 'something similar to flicking an electric switch went on when bilinguals switched languages.' ${ }^{6}$ Increasingly, scholars have left this thinking behind, but see the languages of bilinguals as much more fluent, sometimes even forming a mixed discourse. ${ }^{7}$ Although some utterances containing more than one language may have a base language, this is not always the case.

The advent of code-switching in the $X$-Men comics coincide with the introduction of a new team in Giant-Sized X-Men \#1, written by Len Wein. Whereas the original team had been homogenous, consisting only of American, white teenagers, all of whom but one were male, this new team, developed significantly by Chris Claremont, who took over the scripting in Uncanny X-Men (here abbreviated UX for convenience) \#94 and remained head writer until 1991, was considerably more diverse. Many different nationalities, ethnicities and religions were represented. The title team of the spin-off New Mutants (here abbreviated NM), launched in 1983, was similarly diverse. Characters express their national, ethnic and religious identities in a number of ways, such as through costumes (both civilian and 'uniform') and speech patterns. Several characters who are not native English-speakers regularly code-switch. For this study, I focus on the issues of Claremont's first ten years of UX (\#94-183), and the first four years of NM (\#1-54), which have been republished by Marvel in recent years. ${ }^{8} 9$ The statistics presented are based on half of this material, in the case of UX the first ten of every twenty issues, in the case of NM the first five of every ten. This will allow analysis of the early appearances of the characters, and chart changes as the story progresses.

In UX, the regular code-switchers are Colossus (Piotr Rasputin, who codeswitches into Russian) and Nightcrawler (Kurt Wagner, who code-switches into German). In NM, Karma (Xi' an Coy Manh, from Vietnam, who code-switches into French) and Sunspot (Roberto DaCosta, from Brazil, who code-switches into Portuguese) code-switch regularly. Some minor characters code-switch too, in 
particular Mariko Yashida, Wolverine's fiancée. However, in the table above, I have included only the four main characters who code-switch regularly.

Table 1: Code-switching in UX \#94-103, 114-123, 134-143, 154-163 and 174-183, and NM \#1-5, 11-15, 21-25, 31-35, 41-45 and 50-54, ordered according to character, comic and type of word/clause.

\begin{tabular}{|l|c|c|c|c|c|}
\hline \multirow{2}{*}{$\begin{array}{c}\text { Character } \\
\text { (Language) }\end{array}$} & \multicolumn{2}{c|}{$\begin{array}{c}\text { Colossus } \\
\text { (Russian) }\end{array}$} & $\begin{array}{c}\text { Nightcrawler } \\
\text { (German) }\end{array}$ & $\begin{array}{c}\text { Karma } \\
\text { (French) }\end{array}$ & $\begin{array}{c}\text { Sunspot } \\
\text { (Portuguese) }\end{array}$ \\
\cline { 2 - 6 } & UX & NM & UX & NM & NM \\
\hline Adjective & 1 & - & 1 & 1 & - \\
\hline $\begin{array}{l}\text { Affirmatives/ } \\
\text { negatives }\end{array}$ & 3 & - & 5 & 6 & - \\
\hline Appellative/name & 26 & 1 & 49 & 25 & 14 \\
\hline Entire clause & - & - & 4 & 12 & - \\
\hline Exclamation & 3 & 2 & 28 & 6 & 3 \\
\hline Greeting & 1 & - & 6 & 2 & 1 \\
\hline Interrogative & 1 & - & 3 & 3 & 1 \\
\hline Noun phrase & 2 & - & 4 & 3 & 2 \\
\hline Thanks & - & - & 3 & 3 & 2 \\
\hline Total & & & 103 & 61 & 23 \\
\hline
\end{tabular}

Code-switching in UX and NM is depicted as the brief flicks of a linguistic switch imagined by early bilingualism scholarship. Although entire clauses occur occasionally, most switches are brief, either in the form of tags or intrasentential noun phrases. Verbs almost never occur outside entire clauses. Code-switching often occurs in light-hearted contexts, such as when addressing other team-mates, e.g. Nightcrawler's 'meine Freunde,' Karma's 'mes amis' and Sunspot's 'mi amigos' ('my friends'). ${ }^{10}$ It also occurs often in taunts during fight scenes, e.g. in UX \#95, when Nightcrawler addresses his froglike opponent as 'Herr Frosch' ('Mister Frog') throughout the fight. On occasion, code-switching will be used in different contexts, especially in the form of exclamations or sentences expressing surprise or distress (e.g. 'mein Gott!', i.e. 'my God!', 'ma mére [sic]! 
Ma [sic] pére [sic]! C'est impossible!', i.e. 'my mother! my father! It's impossible!'). ${ }^{11}$ Sometimes code-switching even occurs in thoughts, but this is more likely to be an attempt to keep a distinguishable idiolect (the specific speech habits of an individual) even in thought balloons, rather than an indication that these characters think in accented English. ${ }^{12}$

The interlocutor is, unlike in real-life code-switching, seemingly unimportant. ${ }^{13}$ Characters who code-switch do so regardless of the interlocutor (even in thoughts), this person's proficiency in the language and their relationship to the speaker. Accommodation lies instead with other characters, who occasionally mirror codeswitches. Colossus is addressed as 'tovarisch' ('comrade') in UX \#163 (by Carol Danvers) and in NM \#23 (by a multilingual bartender). In UX \#104, Nightcrawler greets two perplexed Scottish men in German, one of whom urges the other, 'dinna answer yon deutsche beastie', an utterance combining dialect and code-switch.

Code-switches often tend to occur together, within the same panel or page. In NM \#43, Karma and Magma both code-switch (into French and Latin respectively) when greeting Sunspot. In UX \#160, Nightcrawler and Colossus answer the same question with 'nein' and 'nyet' ('no'). In UX \#121, Nightcrawler meets the Canadian superhero Aurora, whom he addresses as 'fräulein' while she addresses him as 'm'sieu'.

Appellatives and forms of address are by far the most common form of codeswitching, occurring 115 times in total. As tagswitches, they are exceedingly easy to incorporate, as they do not disturb the structure of the sentence. Most often, the appellative is a title (e.g. 'fräulein') or a noun phrase (e.g. 'mes braves', 'my good friends'), but on occasion, names are translated. ${ }^{14}$ During a fight in UX \#142, Nightcrawler addresses the mutant Avalanche as 'Herr Lawine,' not only giving him a German title but also translating his mutant name literally. In NM \#43, Karma greets Sunspot, 'Bonjour, Robert.' Sunspot's first name is Roberto, so 'Robert' must be the French equivalent, not the English. The X-Man Kitty Pryde's name seems particularly prone to translation - Nightcrawler calls her 'Katzchen' ('little cat'), and Colossus calls her Katya. ${ }^{15}$

Characters who code-switch all have recurring set phrases. The phrase most commonly used by Colossus is 'tovarisch' (seventeen times). Nightcrawler's most common phrases are 'mein Gott!' (eleven times), 'ach!' (nine times) and various appellatives, in particular constructions with the title Herr (seventeen times), e.g. 'Herr Professor', referring to Charles Xavier. Karma's most common phrase is also an appellative, 'm'sieu' (twelve times), used primarily for Xavier and Magneto (who acts as headmaster of the mutant school from NM \#35). Sunspot, who codeswitches least of these characters, has only a few recurring phrases, all appellatives, 'menina' ('girl'), 'senhor' ('mister') and 'amigos' ('friends'), all three times each. In UX, it takes some time before these idiolectic quirks are established. Early on, the non-English phrases are more varied. Colossus' use of 'tovarisch' ('comrade') is not as common, and Nightcrawler uses terms he later does not, e.g. 'Der 
Jahrmarkt' ${ }^{16}$ In NM, the idiolects are shown as being fairly consistent throughout. Presumably by 1983 , when NM was launched, Claremont had found a way of representing code-switching with which he was comfortable.

Code-switches are almost always rendered in the Latin alphabet. Although other scripts would make the code-switches more graphically obvious, it makes parts of the character's speech more or less inaccessible to most readers. The exception to this rule is three of Colossus' five earliest code-switches in UX \#94-102: 'A squad of американский soldiers', 'Take that веэумный [sic] уеповек [sic]' and 'профе́сc⿻p Xavier'. ${ }^{17}$ While the first two are (attempts at) Russian words, the third is only shown to be a code-switch by the script, as the transcription would have been identical to the English. The Cyrillic alphabet has evidently caused trouble for the letterer. The second should in fact be 'безумный человек' ('mad man') $-<\sigma>$ have been confused with $<$ B $>$, which looks like the Latin $<b>$. Cyrillic $<_{3}>,<_{\mathrm{Y}}>$ and $<_{\mathrm{J}}>$ have been replaced with the graphically similar $<_{\mathrm{y}}>,<_{\mathrm{y}}>$ and $<_{\Pi}>$. The $<\phi>$ in 'профéccop' is incorrectly written, with the lower bar missing. The accent on the $<\mathrm{e}>$, indicating stress, suggests that the word has been picked from a dictionary. It seems likely that there was a decision after these early issues to write all of Colossus' code-switches in Latin script. The transcriptions are often based on pronunciation rather than the Cyrillic spelling, implying that later codeswitches are not taken from a dictionary but by aural means.

The reasons behind code-switching in the real world are many and varied, and not always fully understood. It can be used (to name a few reasons) to express group identity, to emphasise nuances in meaning, to make a statement more indirect or more humorous, to include (and exclude) listeners and to avoid lexical gaps. Code-switching is sometimes a conscious process, but studies indicate that many speakers do it without thinking. ${ }^{18}$

This leads us to the question of why code-switching plays such a major role in several characters' speech in the comics. Stan Lee has claimed that '[p]erhaps the most important element in the so-called Marvel style is the fact that we have to stress realism in every panel. [---] The trick is to create a fantastic premise and then envelop it with as much credibility as possible.' ${ }^{19}$ Sharon Walshe argues that Marvel's use of accents and dialects is part of this, but also shows that the Irish accents in Marvel are often 'Stage Irish' and sometimes includes Scotticisms. ${ }^{20}$ There are mistakes in all recurring languages, both in grammar ('ma pére' for French 'mon père', 'my father', 'mein klein Freund' for German 'mein kleiner Freund', 'my little friend') and in spelling ('todt' for German 'tot', 'dead', 'hei' for Japanese 'hai', 'yes'). ${ }^{21}$ On several occasions, Sunspot, whose first language is explicitly stated at his first appearance in the New Mutants Graphic Novel (1982) as Portuguese, is shown code-switching into Spanish. In NM \#5, it is even claimed that he speaks Spanish. This mistake presumably stems from the large number of Spanish-speaking countries in South America, and Brazil's uncommon status as Portuguese-speaking. The mistakes in the Cyrillic script have already been touched 
upon. Furthermore, the realism is undermined by the fact that the social situations where code-switching often takes place - among fellow bilinguals - are absent. Instead, characters code-switch seemingly independently of their surroundings and their listeners.

This leads to the possibility that the code-switching is in fact representative of something greater - part of an idiolect which in turn is part of an identity. Frequent code-switching invites the reader to imagine the character speaking with an accent. It is no surprise that every time Nightcrawler, whose code-switches are most frequent and most closely associated to him as a character, has been depicted onscreen, in the feature film $X$-Men 2 (2003) (by Alan Cummings) and in several animated shows (X-Men (1992-1997), X-Men: Evolution (2000-2003) and Wolverine and the X-Men (2009)), he is portrayed with a strong German accent. Although Colossus does not have an accent in his brief appearance in $X$-Men 2 (played by Daniel Cudmore), he has a distinct accent in both $X$-Men and Wolverine and the X-Men. These distinctive idiolects, which become an integral part of the characters, convey different kinds of identity. In the cases of Nightcrawler, Colossus and Sunspot, the use of the national languages of their country of origin reminds us of the characters' national identity. Colossus' frequent use of the term 'tovarisch' is also a reference to his political convictions. It reminds the reader that he is not just a Soviet national but also a Communist. Karma is never depicted speaking Vietnamese, even to her family, but French is not an arbitrary choice, as Vietnam was part of French Indochina. Her code-switches do not give any clues to her specific nationality, but underline her foreign identity. Her use of religious exclamations, such as 'sacré mère' ('holy mother'), serves a reminder of her Catholic upbringing. ${ }^{22}$

The languages that occur are all recognisable to the reader. The most common Russian, German, Portuguese/Spanish and French (which takes the place of Vietnamese, which would not be recognisable) - are all Indo-European, and spoken in Europe. Vietamese is consciously excluded, as most readers would not recognise or understand it. The only commonly occurring language which is not European is Japanese. Most of the instances of Japanese are either represented by English enclosed in angle brackets (the standard way in Marvel to represent other languages), or given in Japanese followed by a translation in angle brackets. Within this English rendition, there are sometimes code-switches, mainly in the form of honorifics, e.g. 'Mariko-chan', 'Xavier-san'. ${ }^{23}$ It can be no coincidence that UX of the later 1970s and early 1980s features several storylines set in Japan, so soon after the publication of James Clavell's incredibly popular novel Shogun in 1975, which made the American general public more aware of Japanese language and culture (if not always in an accurate way). ${ }^{24}$ The influence of Shogun is seen even in the name of Mariko Yashida, first introduced in \#118 (1979), possibly named after Clavell's character Toda Mariko. 
Despite code-switching being so common, not all characters who are not native speakers of English code-switch, or do so very infrequently. Magma, who is from a lost Roman colony in the Amazon rainforest and therefore has Latin as her mothertongue, only code-switches once in the source-material (the greeting 'avé [sic]', presumably with the macron misinterpreted as an accent), but her Roman heritage is underlined in her speech through her frequent invocations of Roman gods. ${ }^{25}$ Magik, the sister of Colossus, does not code-switch at all. When she first appears, she is a small child who only speaks Russian (represented by English in angle brackets), but after she has been preternaturally aged into adolescence in the demon realm Limbo in UX \#160, she starts speaking English, without any code-switches. Unlike her brother Colossus, Magik does not share in the Russian cultural heritage or Soviet state ideology, which his switches often represent. Storm, the daughter of an American photographer and a Kenyan princess, who grew up in Cairo's slums, never code-switches either, but it is never made clear what Storm's mother-tongue is. Is it English (because of her father)? Is it Kiswahili (because of her mother) or one of the over sixty other languages spoken in Kenya? ${ }^{26}$ Is it Arabic (because of her childhood in Egypt)? Kiswahili, Arabic or tribal languages would not be recognisable to a reader in the way that European languages or Japanese are. It would not help the reader to remember Storm's backstory and her identities, but instead serve to alienate her.

Although he is occasionally shown speaking other languages than English, the sometime-villain, sometime-hero Magneto is never shown code-switching. ${ }^{27}$ Before Chris Claremont's run, Magneto's origin-story was unknown, but in UX $\# 150$, it is established that he is a Holocaust survivor. ${ }^{28}$ It was not revealed until much later (in 2008) that Magneto was originally German, so during this period, it was unknown from which country or even part of Europe he was, and therefore which language he spoke. ${ }^{29}$ Introducing code-switches of any language now that it had been established that Magneto was not a native speaker of English (although he may have been written as non-American from the very beginning) would be a great change in how the character spoke. ${ }^{30}$ Light-hearted, even comical, codeswitches would be an odd contrast to Magneto's formal way of speaking.

However, the most pressing reason as to why Magneto does not code-switch is the implications it has for other characters and their identity. Code-switching shows that the speaker is part of a greater context. Magneto has consciously rejected any such context.

Nor do I accept the dominion of any nation over my person. My land - all the countries of the world - turned their backs on me and mine when we were condemned to Hitler's death camps. Therefore, in return, I have sworn to deny them! ${ }^{31}$ 
Identity and Idiolect

The Holocaust has erased his previous nationality. In \#199, Magneto uses 'me and mine' to refer to the European Jews, but in UX \#200, he uses the very same words to refer to mutants. ${ }^{32}$ His experiences during the Holocaust make him reject national identity, but the hatred against mutants he encounters makes him reject all forms of human identity. The absence of code-switching tells us just as much as the inclusion of it.

The code-switching in Uncanny X-Men and New Mutants of the 1970s and 1980s play an important part in conveying characters' identities. The execution may not be particularly realistic, and the switches may contain mistakes, but realism is not their primary purpose. Along with numerous visual prompts and representations of accents and dialects, this illustration of bilingualism makes the national, ethnic and religious diversity of the team not just a fleeting starting-point, but a defining feature throughout the entire comic, its sequels and its adaptations. Emphasising that mutants have other identities, which they share with other people - national, ethnic, religious and linguistic identities - humanises them further. Ultimately, the practice of code-switching becomes part of the central message of both comics, of everyone's equal value, regardless of their origins or their identities.

\section{Notes}

${ }^{1}$ Shane Walshe,"“Ah, laddie, did ye really think I'd let a foine broth of a boy such as yerself get splattered...?" Representations of Irish English Speech in the Marvel Universe' in Linguistics and the Study of Comics, edited by Frank Bramlett (Basingstoke: Palgrave Macmillan, 2012), 264-290.

${ }^{2}$ I am indebted to Johan Anglemark, Carina Burman, R.B. Griffiths, Anna Judson and Katherine MacDonald for valuable comments which improved this paper.

${ }^{3}$ Shana Poplack. 'Sometimes I'll start a sentence in Spanish y termino en español: toward a typology of code-switching'. Linguistics 18 (1980): 581-618. 583. For more on the intricacies of the terminology of code-switching, see Penelope Gardner-Chloros. Code-switching (Cambridge: Cambridge University Press, 2009), $12-13,122-123$.

${ }^{4}$ Poplack, 'Sometimes I'll start', 615.

${ }^{5}$ Suzanne Romaine. Bilingualism (Oxford: Blackwell Publishing, 1995), 123.

${ }^{6}$ Gardner-Chloros, Code-switching, 11. 
${ }^{7}$ Ibid., 1; Romaine, Bilingualism, 145.

${ }^{8}$ Throughout this article, I will refer to issue numbers, rather than the volumes they are found in. UX \#94-119 can be found in Chris Claremont and Len Wein. Essential X-Men vol. 1 (New York: Marvel Comics, 2006). UX \#120-144 in Chris Claremont. Essential X-Men vol. 2 (New York: Marvel Comics, 2005). UX \#145-161 in Chris Claremont. Essential X-Men vol. 3 (New York: Marvel Comics, 2010). UX \#162-179 in Chris Claremont. Essential X-Men vol. 4 (New York: Marvel Comics, 2006). UX \#180-179 in Chris Claremont. Essential X-Men vol. 5 (New York: Marvel Comics, 2007).

${ }^{9}$ NM \#1-7 can be found in Chris Claremont. The New Mutants Classic vol. 1 (New York: Marvel Comics, 2006). NM \#8-17 in Chris Claremont. The New Mutants Classic vol. 2 (New York: Marvel Comics, 2007). NM \#18-25 in Chris Claremont The New Mutants Classic vol. 3 (New York: Marvel Comics, 2008). NM \#26-34 in Chris Claremont. The New Mutants Classic vol. 4 (New York: Marvel Publishing, 2009). NM \#35-60 in Chris Claremont. The New Mutants Classic vol. 5 (New York: Marvel Worldwide, 2010). NM \#41-47 in Chris Claremont and Jackson Guice. The New Mutants Classic vol. 6 (New York: Marvel Worldwide, 2011). NM \#48-54 in Chris Claremont and Jackson Guice. The New Mutants Classic vol. 7 (New York: Marvel Worldwide, 2012).

${ }^{10}$ In UX \#155, \#158; NM \#5, \#35, \#3.

11 e.g. UX \#99, \#116, \#157; NM \#1.

12 e.g. UX $\# 99$.

13 See Gardner-Chloros, Code-switching, 65-73.

14 UX \#121; NM \#50.

15 e.g. UX \#155, \#160, \#174, \#180.

16 UX \#99, \#104.

17 The first two occurs in UX \#95, the third in UX\#102. The two transliterated code-switches are 'gospodin' (\#94) and 'tovarisch' (\#99).

18 Gardner-Chloros, Code-switching, 15.

${ }^{19}$ Quoted in Walshe, 'Ah, laddie', 270-271. 
${ }^{20}$ Walshe, 'Ah, laddie', 273.

${ }^{21} \mathrm{NM} \# 1$; UX \#140, \#161, \#174.

22 e.g. NM \#34, \#54.

${ }^{23}$ UX \#120, \#181.

${ }^{24}$ Hurst, Cameron C. 'Learning from Shogun', review of Learning from Shogun: Japanese History and Western Fantasy, by Henry Smith. Journal of Asian Studies 41 (1981):158-159.

${ }^{25} \mathrm{NM} \# 43$.

26 'Kenya - Ethnologue', viewed 12 November 2013, http://www.ethnologue.com/ country/KE.

27 e.g. UX \#161, and outside the scope of this paper, Classic X-Men \#23 (1986) and Wolverine \#23 (1988).

${ }^{28}$ It is not stated explicitly that Magneto is Jewish until much later, but it is strongly implied in UX \#161 and 199. See 'The Magneto is Jewish FAQ', last modified 21 February 2009, viewed 12 November 2013, http:// cyberhellfireclub.myfreeforum.org/ ftopic13.php\&sid=209ef010f8fd0fe86b9e221718b7d84c.

${ }^{29}$ Magneto's German origins are established in Greg Pak, X-Men: Magneto Testament. New York: Marvel Worldwide, 2009.

${ }^{30}$ See C.A. Malcolm, 'Witness, Trauma and Remembrance: Holocaust representation and X-Men Comics', in The Jewish Graphic Novel: Critical Approaches, eds. S. Baskind and R. Omer-Sheran, (New Brunswick: Rutgers University Press, 2008), 144-160. 147.

${ }^{31}$ UX \#199.

${ }^{32}$ Malcolm, 'Witness, Trauma and Remembrance', 157. 


\section{Bibliography}

Ben-Rafael, Miriam and Eliezer Ben-Rafael. 'Plurilingualism in Francophone Comics' in Linguistics and the Study of Comics, edited by Frank Bramlett, 142-162. Basingstoke: Palgrave Macmillan, 2012.

Bramlett, Frank. 'Linguistic Codes and Character Identity in Afro Samurai'. In Linguistics and the Study of Comics, edited by Frank Bramlett, 183-209. Basingstoke: Palgrave Macmillan, 2012.

Bramlett, Frank, ed. Linguistics and the Study of Comics. Basingstoke: Palgrave Macmillan, 2012.

Claremont, Chris. The New Mutants Classic vol. 1. New York: Marvel Comics, 2006.

Claremont, Chris and Jackson Guice. The New Mutants Classic vol. 6. New York: Marvel Worldwide, 2011.

Claremont, Chris and Jackson Guice. The New Mutants Classic vol. 7. New York: Marvel Worldwide, 2012.

Claremont, Chris. The New Mutants Classic vol. 2. New York: Marvel Comics, 2007.

Claremont, Chris. The New Mutants Classic vol. 5. New York: Marvel Worldwide, 2010.

Claremont, Chris. The New Mutants Classic vol. 3. New York: Marvel Comics, 2008.

Claremont, Chris. The New Mutants Classic vol. 4. New York: Marvel Publishing, 2009.

Claremont, Chris, and Len Wein. Essential X-Men vol. 1. New York: Marvel Comics, 2006.

Claremont, Chris. Essential X-Men vol. 3. New York: Marvel Comics, 2010.

Claremont, Chris. Essential X-Men vol. 4. New York: Marvel Comics, 2006. 
Claremont, Chris. Essential X-Men vol. 2. New York: Marvel Comics, 2005.

Claremont, Chris. Essential X-Men vol. 5. New York: Marvel Comics, 2007.

Cyber Hellfire Club. 'The Magneto is Jewish FAQ'. Last modified 21 February 2009. Accessed 12 November 2013, http://cyberhellfireclub.myfreeforum.org/ ftopic13.php\&sid=209ef010f8fd0fe86b9e221718b7d84c.

Ethnologue. 'Kenya - Ethnologue'. Accessed 12 November 2013, http:// www.ethnologue.com/country/KE.

Gardner-Chloros, Penelope. Code-switching. Cambridge: Cambridge University Press, 2009.

Hurst, Cameron C. 'Learning from Shogun'. Review of Learning from Shogun: Japanese History and Western Fantasy, by Henry Smith. Journal of Asian Studies 41 (1981):158-159.

Malcolm, C.A. 'Witness, Trauma and Remembrance: Holocaust representation and X-Men Comics'. In The Jewish Graphic Novel: Critical Approaches, edited by S. Baskind and R. Omer-Sheran, 144-160. New Brusnwick: Rutgers University Press, 2008.

Pak, Greg. X-Men: Magneto Testament. New York: Marvel Worldwide, 2009.

Poplack, Shana. 'Sometimes I'll start a sentence in Spanish y termino en español: toward a typology of code-switching'. Linguistics 18 (1980): 581-618.

Romaine, Suzanne. Bilingualism. Oxford: Blackwell Publishing, 1995.

Walshe, Shane. "“Ah, laddie, did ye really think I'd let a foine broth of a boy such as yerself get splattered...?" Representations of Irish English Speech in the Marvel Universe' in Linguistics and the Study of Comics, edited by Frank Bramlett, 264-290. Basingstoke: Palgrave Macmillan, 2012.

Annie Burman is a $\mathrm{PhD}$ student in linguistics and philology at the Faculty of Classics, Cambridge. Her research interests include language classification, bilingualism and language contact in both the ancient and the modern world. 